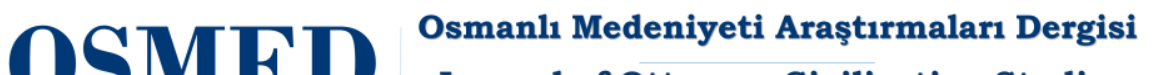 Journal of Ottoman Civilization Studies

\section{Osmanlı Devleti'nde Siyasal Bir Ritüel: Kılıç Kuşanma Merasimi (XVIII. Yüzyıl) \\ A Political Ritual in the Ottoman State: Gird Oneself with a Sword Ceremony}

\author{
Uğru Kurtaran \\ Doç. Dr. \\ Karamanoğlu Mehmetbey Üniversitesi \\ Tarih Bölümü \\ ugurkurtaran@gmail.com \\ ORCID ID : 0000-0002-6394-408X
}

\author{
Zeynep Karaca \\ Doktora Öğrencisi \\ Karamanoğlu Mehmetbey Üniversitesi \\ Tarih Bölümü \\ z.karaca90@gmail.com \\ ORCID ID : 0000-0002-3085-1880
}

\section{Makale Bilgisi / Article Information}

Makale Türü / Article Type : Araştırma Makalesi

Geliş Tarihi / Received : 3 Haziran 2021

Kabul Tarihi / Accepted : 16 Temmuz 2021

Yayın Tarihi / Published : 15 Ekim 2021

DOI Number : 10.21021/osmed.947472

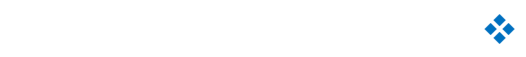

Kaynak Gösterme / Citation

Kurtaran, U. \& Karaca, Z. “Osmanlı Devleti'nde Siyasal Bir Ritüel: Kılıç Kuşanma Merasimi (XVIII. Yüzyıl)". Osmanlı Medeniyeti Araştırmaları Dergisi, 13 (2021): 83-100.
\end{abstract}




\title{
Osmanlı Devleti’nde Siyasal Bir Ritüel: Kılıç Kuşanma Merasimi (XVIII. Yüzyıl)
}

\author{
A Political Ritual in the Ottoman State: Gird Oneself with a Sword Ceremony
}

\section{Ŭgur Kurtaran \& Zeynep Karaca}

\section{$\ddot{O z}$}

Osmanlı Devleti'nde kuruluş yıllarından itibaren padişahların tahta çıkışlarında gerçekleştirilen kııı̧ kuşanma merasimleri zamanla saltanatın meşruîyeti için gerekli bir siyasal uygulama haline gelmiştir. Osmanlı devlet geleneğinde saray dışında düzenlenen merasimler arasında yerini alan ve resmi belgelerde "taklid-i seyf, takallüd-i şemşîr" şeklinde geçen bu törenler, 17. yüzyıldan itibaren resmiyet kazanmıştır. Çalışmada, Osmanlı devlet teşrifatında önemli bir yeri olan kıııç kuşanma merasimlerinin nasıl icra edildiği ile ilgili bilgiler yer almaktadır. Araştırma Osmanlı Devleti'nde uygulanan kılıç kuşanma merasimlerinin 18. yüzyılda nasıl gerçekleştiğini incelemeye yöneliktir. Bu noktada çalışmada genelden özele bir indirgeme yapılmak suretiyle, Osmanlı Devleti'ndeki genel kılıç kuşanma merasimlerinin, 18. yüzyıl padişahları tarafından nasıl uygulandığına dair değerlendirmeleri bulmak mümkündür. Bunun için yüzyılın ilk padişahı Sultan III. Ahmed'ten başlanarak, son padişahı III. Selim'e kadarki diğer padişahların kılıç kuşanma merasimlerinin ayrıntıları yer almaktadır. Çalışmaya öncül oluşturan kaynakların incelenmesinin ardından öncelikle geniş bir perspektiften yaklaşılarak konunun kavramsal çerçevesi oluşturulduktan sonra, temel sorunsalı ortaya çıkartacak somut veriler elde edilmiştir. Makale sonucunda ise 18. yüzyılda Osmanlı devlet ve toplum yapısındaki köklü değişimlerin, kılıç kuşanma merasimlerine tesir etmediği gözlemlenmiştir. Son tahlilde ilgili yüzyılda dönemin kendi şartları gereğince yaşanan küçük değişiklikler dışında kılıç kuşanma merasimlerinin bir önceki yüzyıllardaki gibi icra edildiğini, anlam ve önemini ise bir sonraki yüzyıla taşıdığını söylemek mümkündür.

Anahtar Kelimeler: Osmanlı Devleti, 18. Yüzyıl, Kılıç Kuşanma, Merasim, Teşrifat.

\section{Abstract}

In the Ottoman Empire, the sword-wielding ceremonies held at the enthronement of the sultans since the foundation years have become a necessary political practice for the legitimacy of the sultanate. These ceremonies, which took their place among the ceremonies organized outside the palace within the Ottoman state tradition and are mentioned as "taklid-i seyf, takallüd-i şemşîn" in official documents, have been official since the 17th century. In the study, there is information about how the swordwearing ceremonies, which have an important place in the Ottoman state ceremony, were performed. The research is aimed at examining how the sword-wearing ceremonies in the Ottoman Empire took place in the 18th century. At this opint, it is possible to find evaluations o how the general swordwearing ceremonies in the Ottoman Empire were practiced by the sultans of the 18th century by making a reduction from the general to the specific in the study. For this, the first sultan of the century, Sultan III. Starting from Ahmed, the last sultan details of the sword-wearing ceremonies of other sultans up to Selim III are inclued. After examining the sources constituting the premise of the study, firstliy, by approacing from a broad perspective and creating the conceptual framework of the subject, concrete data that will reveal the main problematic were obtained. In the final analysis, it is possible to say that the sword-wearing ceremonies were performed as in the previous centuries and that they carried their meaning and importance to the next century, except for a few minor changes in the relevant century by the conditions of the period.

Keywords: Ottoman State, 18th Century, Swords, Ceremony, Order 


\section{Giriș}

Atlı göçebe kültürden imparatorluğa geçilen süreç içerisinde Türklerin elinden ve belinden eksik etmediği kılıç, hem etkili bir savaş aleti hem de zengin çağrışımları simgeleyen bir araç olarak dikkat çekmektedir ${ }^{1}$. Dünyevî ve dinî birçok anlamı içinde barındıran kılıç, güç, hâkimiyet ve adalet gibi sembollerin yanısıra, ihtiyat ve yok etmenin sembolü olarak da ön plana çıkmaktadır. $\mathrm{Bu}$ da k1lıcın kültürle olan ilişkisi itibariyle savaş aleti olmanın çok ötesinde bir anlamı içinde barındırdığını gösterir². Arapçada genellikle "helak etmek" manasını taşıyan "seyf", Farsçada "kılıç" Osmanlıcada ise "şemşir" kelimesi ile ifade edilmektedir. ${ }^{3}$ Tüm bu anlamlarıyla kılıç, harpte kullanılan, genellikle bir tarafı keskin ve saplı uzun yassı demirden oluşan ve bir kın içinde kayışla tutturularak bele takılan üzerinde süslü motiflerin yer aldığı bir harp aleti olarak tanımlanmaktadır ${ }^{4}$. Bununla birlikte kılıç, Türkler için yalnızca bir savaş aleti olarak görülmez. Manevi olarak da iktidarı temsil eden en önemli sembollerden biridir. Osmanlı devlet geleneğinde de bu inanç doğrultusunda kılıç, her daim hem maneviyatı güçlü bir simge hem de iktidar ve gücün kapısını aralayan bir nesnedir. Osmanlı Devleti'nde eski Türk devlet geleneğinin bir devamı olarak kılıca verilen bu önem kılıcı merasimlerin vazgeçilmez bir simgesi hâline getirmiştir.

Osmanlı saray geleneklerinin vazgeçilmez bir unsuru olarak görülen ve Osmanlı hükümdarlarının saltanat makamına oturmaları nedeniyle düzenlenen kılıç kuşanma merasimleri resmi belgelerde "taklid-i seyf, takallüd-i şemşî̀" olarak tabir edilmektedir. Bu merasimlerde k1liç şeklinde yazılmış padişah fermanlarının yanı sıra kılıcı kuşananın muzaffer olması dileğini simgeleyen kılıç üzerine ayet yazılması geleneği ve merasimler esnasında edilen dualar ile de kılıcın kutsallığına vurgu yapılmıştır ${ }^{6}$. Bu merasimler, ayrıca Osmanlı padişahlarının din savaşçısı özelliklerini vurgulayan en önemli temsil araçlarından birini teşkil etmektedir. İki aşamadan oluşan ritüelin birincisi törenin yapıldığı alana kadar gidişi ihtiva eden kılıç alayı, diğeri de kutsal kabul edilen kılıçlardan en az birinin kuşanmasından oluşan kılıç kuşanma (tören) aşamasıdır ${ }^{7}$. Kılıç kuşanma merasimlerinin ne zaman başladığı ile ilgili ise henüz net bilgiler bulunmamakla birlikte Hz. Peygamberin bazı savaşlarda kılıç kuşandığı gibi bazı sahabelere kılıç kuşatması, kılıç kuşatma geleneğini Asr-1 Saâdet'e kadar götürmeyi mümkün kılmaktadır. Memluk sultanlarına o dönemin Abbasi halifesi hil'at giydirdiği gibi kılıç da kuşatırdı. Selçuklularda da uygulanan bu merasim, Osmanlılara sirayet ederek tarihsel süreçte kendine özgü bir nitelik kazanmıştır. Osmanlı Devleti'nde bu geleneği başlatarak ilk kılıç kuşanan padişah Yıldırım Bayezid kabul edilirken, kılıç kuşanmanın gelenek haline gelmesi ise II. Murad'ın saltanatı ile birliktedir ${ }^{8}$. Osmanlılarda yapılan bu merasim batı âleminde uygulanan kralların kilisede taç giymelerine benzetilmektedir ${ }^{9}$. Ayrıca kılıç alayı I. Ahmed'ten itibaren saltanatın ana sembolü haline gelerek zaman içinde bazı değişimlere uğrasa da Sultan Vahdettin'e kadar bazı istisnalar haricinde icra edilen bir gelenek olarak tarihteki yerini almıştır ${ }^{10}$.

\footnotetext{
${ }^{1}$ GülçinTanrıbuyurdu, "Klasik Türk Şiirinde "Kılıç Duası”, Divan Edebiyatı Araştırmaları Dergisi, (2012), 140-141.

2 Bayram Sevinç, "Yiğit ve Silahlı Adam Diyalektiğinde Kılıç Simgesi”, Turkish Studies, 8/6 (2013), 622.

3 Nebi Bozkurt, "Kılıç", TDV İslâm Ansiklopedisi, 25 (Ankara 2002), 405.

${ }^{4}$ Hilmi Aydın, "Topkapı Sarayı’nda Padişah Kılıçları", El Sanatları Dergisi, 4 (2007), 29.

${ }^{5}$ Cumhurbaşkanlığı Osmanlı Arşivi (bundan sonra BOA):HH. nr. 524/25602; C. SM. nr. 1/29; C. SM. nr. $132 / 6636$.

${ }^{6}$ Gülçin Tanrıbuyurdu, "Klasik Türk Şiirinde "Kılıç Duası", Divan Edebiyatı Araştırmaları Dergisi, (2012), 141.

7 Dündar Alikılıç, Osmanlı'da Devlet Protokolü ve Törenler Imparatorluk Seremonisi, (İstanbul: Tarih Düşünce Kitapları, 2004$), 52$.

8 Abdülkadir Özcan "Kılıç Alayı”, TDV İslâm Ansiklopedisi, 8 (Ankara 2002), 408- 409.

9 Halil İnalcık, "Osmanlı Padişahı", A. Ü. S. B. F. D., C. XIII/IV, (1958), 72.

10 Abdülkadir Özcan "Kılıç Alayı”, TDV İslâm Ansiklopedisi, 8 (Ankara 2002), 408- 409.
} 
Osmanlı padişahlarının İstanbul'un fethinden sonra Eyüp semtinde Halid ibn-i Zeyd Ebu Eyyub-1 Ensâri türbesinde kılıç kuşanmaları bir kaide haline gelmiş ${ }^{11}$ olsa da geleneksellik ibaresi bir kenara bırakılacak olursa kılıç kuşanma merasimlerinin değişmeden kuşaktan kuşağa tekrarlanan yalın bir kutlamadan ibaret olmadığı vurgulanmalıdır ${ }^{12}$. Bu törenler zaman içinde küçük de olsa değişimlere uğradığ1 gibi mutat bir gelenek olmaktan da zaman zaman uzaklaşmıştır. Bu durum Osmanlı Devleti'nde kuruluş yıllarından itibaren uygulanan kılıç kuşanma merasimlerinde yaşanan değişimleri ve bu değişimlerin nedenlerini önemli hale getirmektedir. Nitekim mevcut literatürde Osmanlı Devleti'nin çeşitli dönemlerinde kılıç kuşanma merasimlerinin nasıl icra edildiği ile ilgili önemli eserler bulunmaktadır ${ }^{13}$. Ancak bu merasimlerin XVIII. yüzyılda uygulanışı ile ilgili araştırmaların sayısı nispeten daha azdır ${ }^{14}$. Oysa XVIII. yüzyıl Osmanlı devlet ve toplum yapısında çok önemli yapısal değişimlerin yaşandığ 1 bir yüzyıl olup, bu değişimler saray hayatından toplumsal yapıya kadar pek çok konuyu etkilemiştir. Çalışma bu amaç doğrultusunda hazırlanmış olup, araştırmada kılıç kuşanma merasiminin Osmanlı Devleti'nde uygulanışı ile XVIII. yüzyılda geçirdiği değişimler algısal, siyasal ve manevi boyutuyla incelenmiştir. Bu noktada çalışmanın temel problematiğinde genelden özele bir indirgeme yapılmak suretiyle, Osmanlı Devleti'nde siyasal bir ritüel olarak uygulanan kılıç kuşanma merasimlerinin XVIII. yüzyıldaki uygulamalarının nasıl olduğu üzerinde değerlendirmelerde bulunulmuştur.

\section{Kılıç Kuşanma Merasiminin İlk Perdesi: Cülus Töreni}

Tahtın yeni sahibine törenle devredilmesi geleneğinin bir uzantısı olarak cülus merasimleri kılıç kuşanmanın başlangıç noktasını temsil etmesi bakımından önemli bir yere sahiptir. Sözlük anlamı olarak oturmak anlamına gelen "cülus" tabiri Osmanlı Devleti'nde şehzadelerin tahta geçişi münasebetiyle düzenlenen töreni ifade etmektedir ${ }^{15}$. Saltanatın sürekliliğinin ve otoritenin devamının tasdiklenmesinin en belirgin ifadesi olan cülus törenleri bu açıdan oldukça önemlidir. Cülus merasimi, devletin düzeninin sarsılması kaygısı ile törenin olabilecek en kısa sürede uygulanmas1 ve yeni hükümdarın tahttaki yerini alması için gerekli bir tören olarak Osmanlı Devleti'nde padişah değişimlerinde mutat bir şekilde uygulanmıştır $^{16}$. Tahta kimin geçeceği belirlendikten sonra Müneccimbaşı hükümdarın tahta geçeceği zamanın uygun saat dilimini hesaplar ve Saat-i Muhtar adı verilen uğurlu an gelinceye dek tüm hazırlıkların tamamlanmasına özen gösterirdi. Söz konusu hazırlıklar içinde törene iştirak edeceklerin Teşrifatçı tarafından bildirilmesi de yer almaktaydı. Buna göre Teşrifatçı törene kimlerin katılacağını belirler, hazırlanan tezkirelerde tören elbiseleriyle güneş doğmadan önce sarayda bulunmaları gerektiği

11 İsmail Hakkı Uzunçarşılı, Osmanlı Devleti’nin Saray Teşkilâtı, (Ankara: TTK Yayınları, 2014), 179.

12 Cemal Kafadar, “Eyüp’te Kılıç Kuşanma Törenleri”, Eyüp: Dün/Bugün Sempozyum 11-12 Aralık 1993, (haz. Tülay Artan), İstanbul 1994, 51.

13 Osmanlı Devleti'nde kılıç kuşanma merasimi ile ilgili yapılan başlıca çalışmalar için bkz. Dündar Alikılıç, Osmanlı'da Devlet Protokolü ve Törenler Imparatorluk Seremonisi, (İstanbul: Tarih Düşünce Kitapları, 2004); Vedat Günyol, "Kılıç Alayı", İslâm Ansiklopedisi, 6 (İstanbul 1977), 678-679; Cemal Kafadar, “Eyüp’te Kılıç Kuşanma Törenleri”, Eyüp: Dün/Bugün Sempozyum 11-12 Aralık 1993, haz. Tülay Artan, (İstanbul 1994), 50-61; Abdülkadir Özcan "Kılıç Alayı", TDV İslâm Ansiklopedisi, 8 (Ankara 2002), 408- 410; Abdülkadir Özcan, "İstanbul'da Cülus ve Kılıç Kuşanma Törenleri”, Antik Çağdan XXI. Yüzyıla Büyük İstanbul Tarihi, Siyaset ve Yönetim II, 3, (İstanbul 2015) 384-395; İsmail Hakkı Uzunçarşılı, Osmanlı Devleti'nin Saray Teşkilâtı, (Ankara: TTK Yayınları, 2014).

${ }^{14}$ XVIII. yüzyılda ve sonrasında kılıç kuşanma merasimi ile ilgili yapılan başlıca çalışmalar için bkz. Hakan T. Karateke, Padişahım Çok Yaşa Osmanlı Devleti'nin Son Yüzyılında Merasimler, (İstanbul: Türkiye İş Bankası Kültür Yayınları, 2017); Arzu Tozduman Terzi, "Sultan Abdülaziz'in Kılı̧̧ Kuşanma Merasimi”, Osmanlı'nın izinde Profesör Dr. Mehmet ipşirli Armağanı, II, haz. F. M. Emecen, İshak Keskin, Ali Ahmetbeyoğlu, (İstanbul: Timaş Yayınları 2013).

${ }^{15}$ Abdülkadir Özcan, “Cülus”, TDV İslâm Ansiklopedisi, 8 (İstanbul 1993), 108.

16 Özlem Günday Koparal, “Osmanlı Minyatürlerinde Merasim Tasvirleri”, (yüksek lisans tezi, Dokuz Eylül Üniversitesi, 2019 ), 26. 
belirtilerek Divan çavuşları tarafından ilgililere ulaştırılırdı. Bu arada Sadrazam ve Şeyhülislâm Hırka-i Saadet Odasında biat ederek divana gelir ve cülus töreninin başlamasını burada beklerlerdi. Merasimlere katılacak olanların sıraları Teşrifatçı aracılığıyla bir defterde kayıt altına alındıktan sonra cülus merasimi de uğurlu saatin geldiği haberinin ardından yeni padişah, başında sorguçlu kavuğu bulunduğu halde sağ koltuğunda Dârüssaâde Ağası, sol koltuğunda Silahdar Ağa ile birlikte selam vererek dışarı çıkardı. Ardından buradaki görevlilerin tümüne selam veren padişah, Bâbüssaâde önünde kurulmuş olan tahta otururken mehterhane çalard1. Bu esnada avluyu dolduran askerler koro halinde "Aleyke AvnullahMaşallah" diyerek alkış tutarlardı. Böylelikle padişahın tahta oturması töreni başlamış olurdu. Tahta yeni geçen padişaha kanun gereği nakibüleşraf yeniden biat ederdi. Nakibüleşrafın ardından geri kalan saray zabitleri rütbe sıralarına göre gelerek biat ederlerdi. Tören sırasında alkış çavuşları padişahın devlet adamlarından kime ayağa kalkacağını, kimin tebrikini oturarak kabul edeceğini belirgin hale getirirlerdi. Nitekim teşrifat bakımından karıştırmaması için ayağa kalkması gerekenlere "hareket-i hümâyun padişahım, devletinle bin yaşa" oturması gerektiğinde de "istirahat-1 hümâyun padişahım, devletinle bin yaşa" sözleriyle haber verirlerdi. Cülus töreninin bitişini Teşrifatçı padişahın eteğini öperek haber verirdi. Padişah bunun üzerine huzurda bulunanları selamlayarak Has Odada biraz dinlendikten sonra ölen hükümdarın cenazesine katılırd ${ }^{17}$. Törenin geri kalan kısmında teşrifat gereği özel uygulamalara geçilerek sırasıyla Kırım hanzadeleri, rikab-1 hümayun ve kapıcıbaşı ağalar biat ederlerdi. Yeni padişah cülustan sonra gelenek olarak sakal bırakırdı. Yeni hükümdar sadarete gönderdiği hatt-1 hümayunda sadrazamı ve kabinesini yerinde bıraktığına dair bilgi verir ardından bu vesileyle tüm devlet erkanına "umûm hil'ati" adiyla hil'atler giydirirdi ${ }^{18}$.

\section{“Karaların ve Denizlerin Hâkimi” Padişah Adına: Kılıç Kuşanma Merasiminin Uygulanışı}

Kılıç kuşanma töreninin gerçekleşmesinin ilk adımı olan cülus merasimi bazı teşrifat kuralları uygulanarak sona erdiğinde padişahın iktidar sahibi oluşunun meşrulaşması kılıç kuşatma ile manevi ve resmi bir hüviyete bürünürdü. Zira biat törenini de kapsayan cülus merasimi sarayda yapılırken, kılıç kuşanma töreni saltanat merkezinin dinî açıdan kutsal mekânı olan Eyüp Sultan Türbesi'nde yapılırdı ${ }^{19}$.

Padişah tahta oturduktan sonra iki veya yedinci gün arasında gerçekleşen bu uygulama için karadan ya da denizden gidilmek suretiyle bir alay tertip edilirdi. Bu alaya "kılıç alayı" adı verilirken, kılıç alayı kılıç kuşanma merasiminin tören aşamasının başlangıç noktasını oluşturup törenin yapılacağı alana ulaşımı ifade etmekteydi. İki şekilde gerçekleştirilebilen bu eylemin kara ve deniz yoluyla yapılabilmesinin simgesel anlamı padişahın hem denizlerin hem de karaların hâkimi olduğu algısının yansıtılmasıyla ilgiliydi. İki aşamalı bu uygulamanın ilki kılıç alayı diğeri ise tören aşamasından oluşmaktaydi.

\section{Saltanata Uzanan Yol: Kılıç Alayı}

Osmanlı padişahlarının saltanat sahibi oluşlarıyla ilgili cülus ve biat gibi törenlerin son halkasını oluşturan kılıç alayı, çoğunlukla padişahların tahta oturmalarının ikinci ile yedinci günü arasında icra edilir ve özellikle ilk Cuma selâmlı̆̆ından önce gerçekleştirilmesi istenirdii ${ }^{20}$.

\footnotetext{
17 Dündar Alikılıç, Osmanlı'da Devlet Protokolü ve Törenler Imparatorluk Seremonisi, (İstanbul: Tarih Düşünce Kitapları, 2004), $32,46,48$.

${ }^{18}$ Abdülkadir Özcan, "İstanbul'da Cülus ve Kılıç Kuşanma Törenleri”, Antik Çağdan XXI. Yüzyıla Büyük İstanbul Tarihi, Siyaset ve Yönetim II, C.3, İstanbul (2015), 384.

19 Hakan T. Karateke, Padişahım Çok Yaşa Osmanlı Devleti’nin Son Yüzyılında Merasimler, (İstanbul: Türkiye İ̧̧ Bankası Kültür Yayınları, 2017),67.

20 Dündar Alikılıç, Osmanlı'da Devlet Protokolü ve Törenler Imparatorluk Seremonisi, (İstanbul: Tarih Düşünce Kitapları, 2004), 54; Cem Görür, "Sultan III. Mustafa: Ailesi, Günlük Hayatı, Dini ve IIlmi Illgileri”, (doktora tezi, Şeyh Edebali Üniversitesi, 2020$), 3$.
} 
Padişahlar kılıç kuşanmaya kara veya deniz yoluyla giderlerdi. Deniz yoluyla gidilmişse kara yoluyla dönülürdü ${ }^{21}$. Daha sonra padişahın saltanatın sahibi olușunun resmi olarak kutlanıșının ilanı niteliğindeki kılıç alayı için tezkireler hazırlanıp alaya iştirak edecek olanlar belirlenirdi. Tezkirede adı bulunan davetliler sabahın erken saatlerinde resmi serpuş ve elbiseleriyle saraydaki yerlerini alırlardı. Bu esnada kapıkulu ocaklarının da hazır bulunmaları emredilirdi ${ }^{22}$. Deniz yoluyla gelmeyi tercih eden padişah, sabah namazından sonra Harem-i Hümâyun'dan çıkıp ata binerek deniz kenarında bulunan Sinan Paşa Köşkü'ne gelip, buradan maiyetinde bulunanlarla birlikte üç fenerli saltanat kayığına binmek suretiyle Eyüp İskelesi’ne doğru yola çıkardı. Bu sırada padişahın kayığına diğer görevlilerin bulunduğu kayıklar eşlik ederdii ${ }^{23}$. Burada en önemli husus, büyük kalabalıkların seyredebileceği biçimde uzun bir yol güzergâhının izlenmesiydi ${ }^{24}$. Bu şekilde yeni padişahın tahta çıkışı meşrulaştırılmış olurdu.

Deniz yoluyla kılıç alayına katılmayı tercih eden padişah iskeleye geldiğinde orada kendisini bekleyen devlet erkanından bir takım görevlilerce karşılanırdı. İskeleye çıkan hünkâr, yemek için hazırlanan konağa götürülürdü. Burada biraz istirahat eden padişah, öğle namazını kılıp yemekten sonra atına binerek önünde Vezir-i azam, Vezirler ve diğer devlet erkânı ile birlikte yola çıkar ve Eyüp Sultan türbesine giderdi ${ }^{25}$. Padişahın Eyüp'ten saraya dönüşü sıklıkla kara yoluyla olurdu. Bu minvalde Edirnekap1, Fatih ve Divanyolu'ndan geçerek Topkapı Sarayı'na gelen padişah, Bâbüssaâde önünde Yeniçeri Ağası tarafından atından indirilerek içeri girmesi kılıç alayının sona erdiğinin işareti olurdu. Padişahın türbe ziyaretinin ardından Eski Odalar önünde altmış birinci cemaat ortası odabaşısının sunduğu şerbeti içmesi ve şerbet kâsesini altınla doldurması mutat bir hal almıştı ${ }^{26}$. Ayrıca yine adet olduğu üzere Odabaşı üç kurban keserdi. Merasim bu şekilde son şeklini alınca padişah Taht Odası'na gitmek için Valide Taşlığı'ndan yaya olarak Altın Yol olarak anılan yola girerek bu yolda kendisini bekleyen Harem halkına altın serperdi ${ }^{27}$.

Kılıç Alayı'nın kara yoluyla tören alanına yürüyüşü deniz yoluyla ulaşımından daha gösterişli ve hareketli olurdu. Öncelikle alaya katılacak olan görevlilerin hepsine bir gün önceden haber verilirdi ${ }^{28}$. Kılıç Alayı günü geldiğinde askerler sabah sarayın birinci avlusunda toplanırdı. Devlet ricali önde gider; arkalarında Sadr-1 âzam ile Şeyhülislâm yürür onların arkasında da saray mensupları yürürlerdi ${ }^{29}$. Alay, Fatih Sultan Mehmed Camii'ne vardığında padişah attan inip, türbeyi ziyaret ederek dua ederdi. Devamında Edirne Kapısı'ndan çıkılarak alay ile Eyüp Sultan Türbesi'ne gidilirdi. Burada tören alayı Eyüp Camii'ne giderek yol tarafina dizilip hazır vaziyette selam dururlard $1^{30}$.

Kılıç alayı yalnızca türbeye ulaşmakla görevli bir birlik değildi. Aynı zamanda alay, farklı görevler de icra ederek padişahın halkla temasında önemli rol oynardı. Bu görevlerden bazıları kırk elli civarında hayvanın kurban edilmesi ve etlerinin cami ve türbe hademeleriyle fakirlere dağıtılması, Eyüp’ten dönüş

${ }^{21}$ Arzu Terzi Tozduman, "Sultan Abdülaziz'in Kılıç Kuşanma Merasimi”, Osmanlı'nın İinde Profesör Dr. Mehmet ipşirli Armağanı, C. II, haz. F. M. Emecen, İshak Keskin, Ali Ahmetbeyoğlu, (İstanbul Timaş Yayınları, 2013), 467.

22 İsmail Hakkı Uzunçarşılı, Osmanlı Devleti’nin Saray Teşkilâtı, (Ankara: TTK Yayınları, 2014), 184.

23 Dündar Alikılıç, Osmanlı'da Devlet Protokolü ve Törenler Imparatorluk Seremonisi, (İstanbul: Tarih Düşünce Kitapları, 2004), 56; Abdülkadir Özcan "Kılıç Alayı", TDV İslâm Ansiklopedisi, 8 (Ankara 2002), 409.

24 Hakan T. Karateke, Padişahım Çok Yaşa Osmanlı Devleti’nin Son Yüzyılında Merasimler, (İstanbul: Türkiye İş Bankası Kültür Yayınları, 2017), 82.

25 İsmail Hakkı Uzunçarşılı, Osmanlı Devleti’nin Saray Teşkilâtı, (Ankara: TTK Yayınları, 2014), 185.

${ }^{26}$ Abdülkadir Özcan "Kılıç Alayı”, TDV İslâm Ansiklopedisi, 8 (Ankara 2002), 409.

27 Dündar Alikılıç, Osmanlı'da Devlet Protokolü ve Törenler Imparatorluk Seremonisi, (İstanbul: Tarih Düşünce Kitapları, 2004$), 58$.

28 Dündar Alikılıç, Osmanlı'da Devlet Protokolü ve Törenler Imparatorluk Seremonisi, (İstanbul: Tarih Düşünce Kitapları, 2004$), 59$.

29 İsmail Hakkı Uzunçarşılı, Osmanlı Devleti'nin Saray Teşkilâtı, (Ankara: TTK Yayınları, 2014),187.

30 Dündar Alikılıç, Osmanlı'da Devlet Protokolü ve Törenler Imparatorluk Seremonisi, (İstanbul: Tarih Düşünce Kitapları, 2004), 5960 . 
sırasında halkın yeni padişaha vermek istediği dilekçelerin toplanmasıydı ${ }^{31}$. Kapıcılar Kethüdası ile Mirahur Ağa tarafından toplanan bu dilekçeleri saraya ulaştıklarında Kapı Ağası mühürleyip Padişah adına, görülüp muamele edilmesi maksadıyla Kapıcılar Kethüdası aracılığıyla sadrazama teslim edilirdi ${ }^{32}$. $\mathrm{Bu}$ anlamıyla kılıç kuşanma merasimleri halkın padişaha ulaşabilmesi için bir vesile olurdu.

\section{Saltanatın Resmileşme İlanı: Kılıç Kuşanma Töreni}

Kılıç kuşanma merasiminin son aşamasını temsil eden tören kısmı zaman içinde büyük değişikliklere uğramadan icra edilen bir uygulamaydı. Kılıç kuşanma töreni bazı istisnalar olsa da genellikle Eyüp Sultan türbesinin ve camiinin bulunduğu yerde gerçekleşirdi ${ }^{33}$. Kılıç kuşanma töreni bir yana bu ziyaretlerin altında yatan en büyük anlamlardan biri de askeri başarı için sahâbenin himmetini almakt1 ${ }^{34}$. XVII. yüzyıl başlarına kadar "türbeler ziyareti" şeklinde olan söz konusu uygulama, I. Ahmed'ten itibaren resmi teşrifattaki yerini ald $1^{35}$. Nitekim XVII. yüzyıl ortalarına kadar "türbeler ziyareti” olarak anılan bu ritüelin ilk sultanların kılıç kuşanma töreninden bağımsız olarak yaptıkları Eyüp ziyaretlerinin yardım dilemek amacıyla yapılmış olması da bunun göstergelerindendir ${ }^{36}$.

Tören gününden önce merasimin yapılmasıyla ilgili usulen de olsa izin takriri yazılıp yeni padişahın irade çıkarması gerekmekteydi. Böylelikle tüm vükela ve ulemaya, devlet ricaline, büyük camilerin şeyhleri ve müderrislere yazılı müzekkirelerle Eyüp'te bulunmaları gereken saat bildirilirdi ${ }^{37}$. Kılıç alayı düzeniyle türbeye ulaşıldıktan sonra padişah türbeye girerek hazırlanan yere oturur, Sadr-1 azamın, Şeyhülislâmın ve Yeniçeri Ağasının gelmesiyle Fetih Suresi okunurdu. Ardından Şeyhülislâm, Nakîbüleşraf ve bazı tarikat üyeleri dua ettikten sonra padişah iki rekât namaz kılıp duasını yapar ve kılıç kuşanırd1 $1^{38}$.

Padişahların kuşandıkları kılıçlar saraydaki emanetler arasından padişahın isteğine göre seçilmekteydi ${ }^{39}$. Osmanlı tarihi boyunca kılıç kuşanma törenlerinde kullanılan kılıçların farklı kişilere ait olması kılıç seçiminin bir kurala bağlı olmadığını göstermektedir. Hz. Ömer, Hz. Peygamber ve Osman Gazi’ye ait kılıçlar son dönemde sıklıkla kullanılan kılıçlar arasındadır. Kimin kılıcının kuşanıldığının önemi ise taşıdığı manevi değer ve simgelediği anlamda gizlidir. Zira IV. Murad Hz. Peygamber ve Yavuz Sultan Selim'in kılıçları olmak üzere çift kılıç kuşanmıştır. II. Mahmud ile II. Abdülhamid'de çift kılıç kuşanan padişahlar arasındadır. Kılıçlardan biri dinî, diğeri ise hanedana dayandırılan görevlendirmenin simgesi olarak karşımıza çıkmaktadır. Burada dikkat edilen husus saray hangi kılıcı kullanırsa kullansın, siyasi malzeme olduğu durumlarda törendeki kılıcın Hz. Muhammed'e atfedilmesiydi. Burada kılıcın verdiği dolaylı mesaj aracılığıyla Osmanlı padişahının halife olarak imgesi

\footnotetext{
${ }^{31}$ Abdülkadir Özcan "Kılıç Alayı", TDV İslâm Ansiklopedisi, 8 (Ankara 2002), 409.

32 Ebru Baykal, "Osmanlılarda Törenler", (yüksek lisans tezi Trakya Üniversitesi, 2008), 33-34.

${ }^{33}$ Arzu Terzi Tozduman, "Sultan Abdülaziz'in Kılıç Kuşanma Merasimi", Osmanlı́nın İzinde Profesör Dr. Mehmet ipşirli Armağanı, C. II, haz. F. M. Emecen, İshak Keskin, Ali Ahmetbeyoğlu, (İstanbul Timaş Yayınları, 2013), 465.

34Feray Coşkun, "Osmanlı İstanbul'unda Müstesnâ bir Ziyaretgâh: Eyüp Sultân Türbesi”, III. Osmanlı İstanbul'u Sempozyum Bildirileri, 1 (İstanbul: 25-26 Mayıs 2015), 559.

35 Abdülkadir Özcan, "İstanbul'da Cülus ve Kılıç Kuşanma Törenleri”, (Antik Çağdan XXI. Yüzyıla Büyük Istanbul Tarihi, Siyaset ve Yönetim II, 3, İstanbul 2015) 387.

${ }^{36}$ Hakan T. Karateke, Padişahım Çok Yaşa Osmanlı Devleti’nin Son Yüzyılında Merasimler, (İstanbul: Türkiye İ̧̧ Bankası Kültür Yayınları, 2017), 69-70.

37 Hakan T. Karateke, Padişahım Çok Yaşa Osmanlı Devleti’nin Son Yüzyılında Merasimler, (İstanbul: Türkiye İ̧̧ Bankası Kültür Yayınları, 2017), 82

38 Abdülkadir Özcan "Kılıç Alayı", TDV İslâm Ansiklopedisi, 8 (Ankara 2002), 409.

39 Vedat Günyol, "Kılıç Alayı”, İslâm Ansiklopedisi, 6 (İstanbul 1977), 679.
} 
pekiştirilmiş oluyordu ${ }^{40}$. Benzer uygulamalar konumuzu teşkil eden XVIII. yüzyıl padişahları tarafından da gerçekleştirilmiştir.

Ayrıca padişahlara kimlerin kılıç kuşatacağı kanuni bir zemine oturtulmamıştır ${ }^{41}$. Çoğu kez bu görevi Şeyhlülislâmlar yerine getirirken, Nakibüleşraftan kimseler de bu görevi en çok icra edenlerdendir ${ }^{42}$. Padişahlara kılıç kuşatma işini normalde ulemayı temsilen Şeyhülislâm ve Hanedan halkını temsil eden Silahdâr Ağası olmak üzere iki kişi icra ederdi ${ }^{43}$. Ancak her padişah döneminde farklı şahısların ortaya çıktığı da görülmektedir. Örneğin Fatih Sultan Mehmed'e hocası Akşemseddin'in kılıç kuşattığı rivayeti de kılıç kuşatanların seçiminin mutlak bir şarta bağlı olmadığını göstermektedir ${ }^{44}$.

\section{Yüzyılda Kılıç Kuşanma Merasimleri}

Görüldüğü üzere Osmanlı tarihinde önemli bir yeri olan ve kuruluş yıllarından itibaren uygulanan kılıç kuşanma törenlerinin XVIII. yüzyılda da bir takım değişikliklerle birlikte uygulandığını söylemek mümkündür. Nitekim dönemin ilk padişahı olan III. Ahmed (1703-1730)'e Nakibüleşraf tarafindan Yeniçeri ve Silahdar Ağa'nın yardımlarıyla kılıç kuşatıldığı bilinmektedir ${ }^{45}$. Buna göre Sultan Ahmed, süregelen geleneğin dışına çıkarak tahta çıkışından (17 Ağustos 1703$)^{46}$ yaklaşık 1 ay sonra (16 Eylül $1703)^{47}$ alayla Eyüp Sultan'a giderek Hz. Halid'in türbesini ziyaretten sonra, Hz. Peygamber'in kılıcını kuşand $1^{48}$. Bir isyan hadisesi (1703 İsyanı) ile Edirne'de tahta çıkan III. Ahmed, İstanbul'a gelerek kılıç kuşand $_{1}{ }^{49}$. Bu arada döneme ait belgelerde padişahın kılıç kuşanma merasimi sırasında mutat bir uygulamaya bağlı kalmak suretiyle Eyüp Sultan türbe hademesine 330 kuruş ihsanda bulunduğu tespit edilebilmektedir ${ }^{50}$.Ardından padişah ve maiyeti törenle Edirnekapı yolundan Topkapı Sarayı'na dönmüştür ${ }^{51}$. Bu şekilde XVIII. yüzyılın hemen başlarında tahta geçen Sultan III. Ahmed, bir kısım küçük farklılıklar ile birlikte tahta çıkışında mutat olduğu şekilde kılıç kuşanma merasimi gerçekleştirdi.

III. Ahmed'in 1730 yılında bir isyan ile tahttan indirilmesinin ardından onun yerine tahta geçen Sultan I. Mahmud (1730-1754) ise tahta çıkışından (1 Ekim 1730) 21 gün sonra Eyüp El-Ensarî türbesini

40 Hakan T. Karateke, Padişahım Çok Yaşa Osmanlı Devleti'nin Son Yüzyılında Merasimler, (İstanbul: Türkiye İ̧̧ Bankası Kültür Yayınları, 2017), 71,74.

41 Bazı Osmanlı Padişahlarına kılıç kuşatanlar şu şekildedir: I. Ahmed'e Şeyhülislam Ebü'l- Meyamin Mustafa Efendi kılıç kuşatmıştır. I. Mustafa, II. Osman ve IV. Mehmed’e Şeyhülislâm kılıç kuşatırken, IV. Murad’a Üsküdarî Aziz Mahmud Hüdaî Efendi kılıç kuşatmıştır. II. Süleyman'a Şeyhülislâm Debbağ-zâde Mehmed Efendi ile Yeniçeri Ağası Mustafa Ağa kılıç kuşatmıştır. III. Ahmed'e Nakibül-eşraf tarafından kılıç kuşatırken, I. Mahmud'a Nakibül-eşraf İmad zâde Seyyit Mehmed Efendi Hz. Peygamberin kılıcını kuşatmıştır. III. Mustafa'ya Şeyhülislâm Feyzullah Efendi ile Nakibül-eşraf ve I. Abdülhamid'e Şeyhülislâm Mehmed Efendi kılıç kuşatmıştır. İsmail Hakkı Uzunçarşılı, Osmanlı Devleti'nin Saray Teşkilâtı, (Ankara: TTK Yayınları, 2014), 180-181.

42 İsmail Hakkı Uzunçarşılı, Osmanlı Devleti'nin Saray Teşkilâtı, (Ankara: TTK Yayınları, 2014), 180.

${ }^{43}$ A. D. Alderson, Osmanlı Hanedanının Yapısı, çev. Şefaettin Severcan, (İstanbul: İz Yayıncılık, 1998) 81.

${ }^{44}$ Ahat Ural Bikkul, "Topkapı Sarayı Müzesindeki Türk Kılıçları Üzerinde Bir İnceleme”, Türk Etnografya Dergisi, IV, (1962): $20-30$.

45 Defterdar Sarı Mehmed Paşa, Zübde-i Vekayiat Tahlil ve Metin (1066-1116/1656-1704), (haz. Abdülkadir Özcan), (Ankara: TTK. Yayınları, 1995), 822; Ruhan Dinç, "18. Yüzyılda Osmanlı Merasimlerinin Mali Bir Unsuru: Atıyyeler”, (yüksek lisans tezi, Fatih Sultan Mehmet Vakıf Üniversitesi 2016), 36.

46 Mehmet Topal, Silahdar Fındıklı Mehmed Ağa, "Nusretname- Tahlil ve Metin (1106-1133/ 1695-1721)", (Doktora Tezi, Marmara Üniversitesi, 2001), 629-631.

47 Ahmet Çağıı Başkurt, "351 Numaralı Sadaret Teşrifat Defteri Işığında Osmanlı Payitahtında İcra Edilen Törenler (H. 11051221/M. 1693-1806)”, (yüksek lisans tezi, Mimar Sinan Güzel Sanatlar Üniversitesi, 2017), 4.

48 M. Münir Aktepe, “Ahmed III", TDV İslâm Ansiklopedisi, 1 (İstanbul 1989), 35.

49 Anonim Osmanlı Tarihi (1099-1116/1688-1704), (Yay. haz. Abdülkadir Özcan), (Ankara: TTK. Yayınları, 2000$), 254$.

50 TSMA. d. , nr.2352.0889.

51 M. Münir Aktepe, “Ahmed III", TDV İslâm Ansiklopedisi, 1 (İstanbul 1989), 35. 
ziyaret ederek kılıç kuşanma merasimini gerçekleştirdi. Geleneğe uygun bir şekilde düzenlenen bu kılıç kuşanma merasiminin, uğurlu kabul edilen Eyüp Sultan Cami'inde gerçekleştirildiği merasime devlet erkânı ile ulemanın katıldığı görülmektedir. Yine önceki dönemlerde olduğu gibi merasim için sabah erkenden saraydan hareket eden I. Mahmud, kendisini karşılayan askeri erkânı selamlayarak alay ile Edirne Kapısı'ndan Eyüp Sultan Türbesi'ne geldi. Bu arada kılıç kuşanma merasimi için toplanan İstanbul halkının önünde yapılan dualar eşliğinde dönemin nakibüleşrafı tarafindan I. Mahmud'a Hz. Muhammed'in kılıcı kuşandırıldı. Ardından Fatih Sultan Mehmed Cami'inde Cuma namazını kılan padişah saraya döndü ${ }^{52}$. Dönemin kroniklerinden Mür'i't-Tevârih adlı eserde ise I. Mahmud'un kılıç kuşanma merasimi şu şekilde açıklanmıştır ${ }^{53}$ :

"Cülusun beşinci Cuma günü Pâdişah kılıç kuşanmak için azim alay ile Edirne-kapısı yolu ile Türbe-i hazret-i Hâlid radiyallahuanh'a varup şemş-i Fahr-i âlem sallalahu te 'âlâ aleyhi ve sellem'i meyânına bend idüp avdetle yine Edirne-kapıst yolundan İstanbul'a dahil olup Ebü'l-feth rahmetullahualeyh câmi 'inde cum 'ayı edâ edüp Saray'a teşrif buyurdu'.

Görüldüğü üzere geleneğe uygun bir şekilde kılıç kuşanma merasimi gerçekleştirilen I. Mahmud'a Hz. Muhammed'in kılıcının kuşandırılmasını Hülya Tezcan, padişahın tahta çıkışı sırasında ön sıralarda duran ve uygunsuz kıyafetleri ve davranışlarıyla devlet erkânını rahatsız eden Patrona Halil ve yandaşlarını doğru yola sevk etmek için yapılan bir uyarı olarak değerlendirilmiştir ${ }^{54}$. Yine I. Mahmud, kılıç kuşanma merasimi için kullanılan yollarda geleneğin dışına çıkarak merasim için kara yolu ile gitmiş ve yine kara yolu ile dönmüştür ${ }^{55}$. Bu durumun özel bir sebebi olmadığını düşünmekteyiz.

I.Mahmud'un vefatı (1754) ile onun yerine geçen III. Osman (1754-1757)'da geleneğe uygun bir şekilde tahta geçişinden (14 Aralık 1754) birkaç gün sonra (20 Aralık 1754) k1lıç kuşanma merasimini icra etti. Buna göre Sultan III. Osman tahtta çıkışının yedinci günü mürettep bir alay ile Saray'dan Eyüp Sultan Türbesi'ne geçti. Yine kendinden önceki padişahların kılıç kuşanma merasimlerinde olduğu gibi hazırlıklar yapılırken, merasime katılacak olan tüm devlet erkânı, sabah erkenden saraya geldi. Fakat hasta olmasından dolayı müsaade isteyen Şeyhülislam Murtaza Efendi, merasimin yapılacağı gün kendi arabasıyla Eyüp Sultan'a geldi ${ }^{56}$. Burada düzenlenen merasimde padişaha Şeyhülislam Seyyid Murtaza Efendi tarafından kılıç kuşandırıld1 ${ }^{57}$. Buna göre 14 Aralık 1754 yılında tahta geçen Sultan III. Osman cülusunun yedinci günü kara yolu ile önce Fatih Sultan Mehmed Türbesi’ne uğradıktan sonra Eyüp Sultan Türbesi'nde kılıç kuşandı. Ardından gelenek olduğu üzere kurbanlar kesilirken, yine Eski Odalar' da şerbet dağıtıld ${ }^{58}$. Merasimin ardından kayıkla Yalı-Köşkü’ne döndü5 ${ }^{59}$. Nitekim bununla ilgili

52 Vak'anüvis Subhî Mehmed Efendi, Subhî Tarihi, haz. Mesut Aydıner, (İstanbul: Kitabevi Yayınları, 2007), 37-38; Necdet Sakaoğlu, "Sultan I. Mahmud", Bu Mülkün Sultanları, (ístanbul 2004), 54; Uğur Kurtaran, Sultan Birinci Mahmud (1730-1754), (Ankara: Altınordu Yayınları, 2018), 63.

53 Şem'dâni-zâde Fındıklılı Süleyman Efendi. Mür'i't-Tevârih, I-II, haz. M. Münir Aktepe, (İstanbul: İstanbul Üniversitesi Edebiyat Fakültesi Yayınları, 1976-1978), 12.

54 Hülya Tezcan, Osmanlı Sarayının Çocukları, Şehzadeler ve Hanım Sultanların Yaşamları, Giysileri, (İstanbul: Aygaz Yayınları, 2006), 121.

${ }^{55}$ Abdülkadir Özcan "Kılıç Alayı”, TDV İslâm Ansiklopedisi, 8 (Ankara 2002), 409.

56 Mehmed Hâkim Efendi, Hâkim Efendi Tarihi,(Osmanlı Tarihi 1166-1180/1752-1766) (Inceleme-Metin), C. I, haz. Tahir Güngör, ed. Ziya Yılmazer, ) İstanbul: Türkiye Yazama Eserler Kurumu Başkanlığı, 2019), 191-192.

57 Fikret Sarıcaoğlu, "Osman III", TDV İslâm Ansiklopedisi, 33 (İstanbul 2007), 456.

58 Mehmed Hâkim Efendi, Hâkim Efendi Tarihi,(Osmanlı Tarihi 1166-1180/1752-1766) (Inceleme-Metin), C. I, haz. Tahir Güngör, ed. Ziya Yılmazer, (İstanbul: Türkiye Yazama Eserler Kurumu Başkanlığı, 2019),196. 
olarak dönemin kroniklerinden "Mehâsinü'l-Âsâr ve Hakâ'iku'l-Ahbâr” adlı eserde “zikr-i taklid-i seyf" başlığıyla merasimin nasıl edildiği ile ilgili bilgiler mevcuttur ${ }^{60}$ :

"Selâtîn ü mülûk-i selef hazret-i Hâlid'de taklîd-i seyf ile kesb-i şeref edegeldikleri kanûn olduğuna binâ'en, şehr-i rebîulevvelin yedinci günü alay tertîb olunup, Sadriazam ve Kapudan Paşa ve sudûr-i ulemâ ve mevâlî ve hâcegân ve müderrisîn ve ocağlu cümle esbâb-ı dîvâniyyeleriyle Serây-ı hümâyûn'da hâzır ve şeyhulislâm Efendi'ye araba ile mukaddemce hazret-i Hâlid'e varup, kudûm-i hazret-i şehriyârî'ye nâzır olmak ruhsatı müteyesser olup, alay âmâde olduğu taraf-ı Tâcdârî'ye ihbâr ve fi'l-hâl şehriyâr-ı vâlâ-tebâr bir esb-i sabâ-reftâra süvâr olup, ilerüden erbâb-ı alay âheste seyr ü hareket ile alâ tefâvüt-i merâtibihim azîmete ibtidâr ve Ebu'l-Feth Sultân Mehmed Hân Câmii'ne duhûl ve rahş-l dilkeşlerinden nüzûl ve cedd-i azamları türbesini ziyâret ile kesb-i feyz-i rûhâniyyet ve Hudâvendigar-l merhûmun hatt-ı yedleriyle nüvişte olan mushaf-ı şerîfi görüp: "Bundan alâ ziyâret olmaz nutkuyla zikr olunan Mushaf-ı şerîf-den bir aşır Kur'an okunmasını fermân ve sevâbıyle revân-ı sâhib-i hattı şâdân buyurdukdan sonra, tekrâr süvâr-l semend-i şevket ve türbe-i hazret-i Hâlid'e gelüp, kesb-i yümn ü bereket ve Nakibu'l-eşrâf Rızâ Efendi dest-güşâ-yı duâ ve deymûmiyyet-i saltanat-l seniyye temennâsını edâ edüp, duâya gayet ve resme nihâyet verildikden sonra taklîd-i seyf maslahatına mübâşeret ve ol dahi vech-i malûm ile pezîr rufte-i temşiyet olup, Hudâvend-i kerrûbî evsâf alay erbâbına ruhsat-dâde-i 'avd ü insırâf olup, o hilâlde zevrak-i hilâl-revnaka süvâr ve âzim-i dâr-l şevket-medâr oldular”.Görüldüğü üzere geleneğe uygun bir şekilde kılıç kuşanan padişah, k1lı̧ kuşandığ1 gün İstanbul'da yangın çıkması nedeniyle padişahın uğurlu gelmediği söylentileri üzerine emekli askerlere bile kanunda olmadığ halde cülus bahşişi dağ $\mathrm{ttr}^{61}$.

Yine dönemin padişahlarından Sultan III. Mustafa (1757-1774)'nın kılıç kuşanma merasiminin de benzer şekillerde gerçekleştiği görülmektedir. Nitekim geleneğe uygun olarak cülusun ikinci ya da beşinci günü icra edilmesi gereken kılıç kuşanma merasimi için III. Mustafa'ya cülusundan hemen sonra (30 Ekim 1757) ${ }^{62}$ bir telhis gönderildi. Telhiste k1lıç kuşanma merasiminin "üçüncü veyahut beşinci günü" yapılmasının "kânun-1 kadîm ve de'b-i müstedîm-i saltanât-1 seniyye" olduğu ifade edildi. Ardından merasim için hangi gün gidileceği ile ilgili padişahtan ferman istenirken, padişahın fermanı doğrultusunda 3 Kasım Perşembe günü alay eşliğinde Sultan III. Mustafa'nın kılıç kuşanma merasimi gerçekleştirildi ${ }^{63}$. Buna göre III. Mustafa'nın kılıç kuşanma merasimi için devlet erkânı seher vakti Topkapı Saray'ında bir araya geldi. Bu çerçevede Sadrazam Ragıb Paşa, Şeyhülislam Feyzullah Efendi ve diğer devlet erkânı sarayda düzenlenecek alay için hazırlandı. Ardından padişah III. Mustafa, Has Oda Kapısı'ndan ata binmek suretiyle, Babüssaade'nin önünden alaya katıldı ve kara yolunu kullanarak Eyüp Sultan Türbesi'ne doğru alay eşliğinde gidildi. Kara yoluyla gidiş ya da dönüşlerde Fatih Sultan Mehmed'in türbesini ziyaret etme geleneğine uyan III. Mustafa, önce alay ile Fatih Türbesi'ne gitti. Bu arada alay, Yeniçerilere ait Eski Odaların önünden geçerken, gelenek gereği altmış birinci bölüğün odabaşısı

\footnotetext{
59 Şem'dâni-zâde Fındıklılı Süleyman Efendi. Mür'i't-Tevârih, I-II, haz. M. Münir Aktepe, (İstanbul: İstanbul Üniversitesi Edebiyat Fakültesi Yayınları, 1976-1978), 178; Nevzat Sağlam, “Ahmed Vâsıf Efendi ve Mehâsinü'l-Asâr ve Hakâ'iku'l-Ahbâr'ı 11661188/1752-1774(Inceleme ve metin)", (Doktora tezi, Marmara Üniversitesi, 2014), 45.

60 Nevzat Sağlam, “Ahmed Vâsıf Efendi ve Mehâsinü'l-Asâr ve Hakâ'iku'l-Ahbâr'ı 1166-1188/1752-1774 (Inceleme ve metin)", (Doktora tezi, Marmara Üniversitesi, 2014), 45.

61 Ruhan Dinç, "18. Yüzyılda Osmanlı Merasimlerinin Mali Bir Unsuru: Atıyyeler”, (yüksek lisans tezi, Fatih Sultan Mehmet Vakıf Üniversitesi 2016) , 34.

62 Kemal Beydilli, “Mustafa III”, TDV İslâm Ansiklopedisi, 31 (İstanbul 2006), 280.

63 Kemal Beydilli, "III. Mustafa (1757-1774) Kaynarca Öncesi bir Padişah Portresi”, Kitab-ı Hedaya, Studien zum Osmanischen Reichundseinen Nachbargebieten, hg. Sevgi Ağcagül-HenningSivert, (Bonn: Bonn Univesity Press 2019) , 194; Cem Görür, "Sultan III. Mustafa: Ailesi, Günlük Hayatı, Dini ve Illmi İlgileri”, (doktora tezi, Şeyh Edebali Üniversitesi, 2020) , 31-32.
} 
tarafindan Sadrazam Ragıp Paşa ve III. Mustafa'ya birer kâse şerbet ikram edildi. Şerbetleri içen padişah mutat olduğu üzere ikram edilen kâseyi altınla doldurmak suretiyle iade ettikten sonra, üç adet kurban kesildi. Buradan sonra Fatih Camii'ne gidilirken, padişah alkışlarla türbeye girdi ve ziyaretini tamamladıktan sonra bir takım ihsanlarda bulundu. Buradan tekrar hareket eden alay, Eyüp Sultan Camii'ne gelince selam vermek suretiyle durdu ve padişah, Sadrazam Ragıp Paşa ile Yeniçeri Ağası'nın refakatinde türbeye girdi. Türbenin içerisinde hazır bulunan Şeyhülislâm ise III. Mustafa'nın türbe ziyaretinden sonra dua ettikten sonra, padişahın tercihine binaen Hz. Ömer'in k1lıcını giydirdi. Daha sonra elli adet kurban kesildi ${ }^{64}$. Bu şekilde kılıç kuşanma merasimini gerçekleştirerek, hükümdarlığının meşruîyetini pekiştiren Sultan Mustafa, Eyüp Sultan türbedarları ile alayda görev alan diğer kişilere çeşitli ihsanlarda bulundu ${ }^{65}$.

Tablo-1: III. Mustafa'nın Kılıç Kuşanma Merasiminde Verilen İhsanlar ${ }^{66}$

\begin{tabular}{|l|l|}
\hline \multicolumn{1}{|c|}{ Kime Verildiği } & \multicolumn{1}{c|}{ Miktar } \\
\hline Eyüb Ensârî türbedarlarına & 500 kuruş \\
\hline Türbe içerisinde Fethi Şerif okuyanlarına & 50 adet zer-i mahbub-1 tam \\
\hline Teşrifaç̧ Efendi'ye & 40 adet zer-i mahbub-1 tam \\
\hline Pişkeşçilere & 15 adet zer-i mahbub-1 tam \\
\hline Mataracılara & 10 adet zer-i mahbub-1 tam \\
\hline İskemleciye & 10 adet zer-i mahbub-1 tam \\
\hline Nevbet-hân-1 Bâb-1 Hümâyûn kullarına & 10 adet zer-i mahbub-1 tam \\
\hline Bölükbaşıŷn-1 Bevvâbân-1 Dergâh-1 Âli kullarına & 10 adet zer-i mahbub-1 tam \\
\hline Sandalcılar ve Piyadecilere & 100 adet zer-i mahbub-1 tam \\
\hline Yeniçeri Hû-keşânlara & 10 adet zer-i mahbub-1 tam \\
\hline Yeniçeri Sakalarına & 4 adet zer-i mahbub-1 tam \\
\hline Maiyetlerine giden Teberdârân-1 Hassa kullarına & 300 kuruş \\
\hline
\end{tabular}

Görüldüğü üzere geleneğe uygun bir şekilde kılıç kuşanma merasimini icra eden III. Mustafa, türbe içerisinde Şeyhülislam'ı ve avluda da devlet erkânını selamladıktan sonra alkışlarla atına binmek suretiyle Bostan İskelesi'ne yöneldi. Burada sadrazam ve yeniçeri ağasının refakatinde kayığa bindi. Ardından Sadrazam Ragıb Paşa'nın “zemin bûs” ederek alkışlanmasıyla birlikte hareket edilerek Topkapı Sarayı'na dönüldü̈ ${ }^{67}$. Nitekim III. Mustafa dönemine ait ruzname ve kroniklerde benzer ifadeler geçmektedir ${ }^{68}$. Fakat bazı kaynaklarda, III. Mustafa'nın kendinden önceki padişah III. Osman gibi, merasim sonrasında saraya dönmeyerek, deniz yolu ile Yalıköşkü'ne gittiğini ifade etmektedir ${ }^{69}$. Döneme ait bir ruzname kaydında bu durum şu şekilde ifade edilmiştir ${ }^{70}$ :

${ }^{64}$ Cem Görür, "Sultan III. Mustafa: Ailesi, Günlük Hayatı, Dini ve Illmi Illgileri”, (doktora tezi, Şeyh Edebali Üniversitesi, 2020), 3233.

65 Bu çerçevede padişahın bizzat kendi hazinesinden verdiği ihsanlar için bkz. Cem Görür, "Sultan III. Mustafa: Ailesi, Günlük Hayatı, Dini ve Illmi Illgileri", (doktora tezi, Şeyh Edebali Üniversitesi, 2020), 33.

${ }^{66}$ Cem Görür, "Sultan III. Mustafa: Ailesi, Günlük Hayatı, Dini ve İlmi Illgileri”, (doktora tezi, Şeyh Edebali Üniversitesi, 2020$), 33$.

${ }^{67}$ Cem Görür, "Sultan III. Mustafa: Ailesi, Günlük Hayatı, Dini ve İlmi Illgileri”, (doktora tezi, Şeyh Edebali Üniversitesi, 2020$), 33$.

68 Üzeyir Yıldırım, "Osmanlılar'da Cülûs ve Buna Dair Bir Kaynak Eser", (yüksek lisans tezi, Mimar Sinan Güzel Sanatlar Üniversitesi 2007) , 33-35; Nevzat Sağlam, “Ahmed Vâsıf Efendi ve Mehâsinü'l-Asâr ve Hakâ'iku'I-Ahbâr'ı 1166-1188/1752-1774 (Inceleme ve metin)", (Doktora tezi, Marmara Üniversitesi, 2014), 97

69 Şem'dâni-zâde Fındıklılı Süleyman Efendi. Mür'i't-Tevârih, I-II, haz. M. Münir Aktepe, (İstanbul: İstanbul Üniversitesi Edebiyat Fakültesi Yayınları, 1976-1978), 13; Yunus Irmak, “III. Mustafa Ruznamesi (H. 1171-1177/M. 1757-1763)", (yüksek lisans tezi, Marmara Üniversitesi 1991), 4.

70 Yunus Irmak, “III. Mustafa Ruznamesi (H. 1171-1177/M. 1757-1763)”, (yüksek lisans tezi, Marmara Üniversitesi 1991), 4. 
"Fî 20 S Ruz-ı Penç-şenbih....Has Oda Kapusu'ndan esb-i sebâ reftare süvâr Babüssaâde'den mutad üzre alay ile kllıç kuşanmağa teşrif Sultan Mehmed Han Türbesi'ni ziyaret, andan Eyyüb türbesine varılub zuhru edâ birle teberrüken Hazret-i Ömer Efendi'mizin mübarek kılıc-ı şerifini kuşanub dua ve senadan sonra sandala süvar Yalıköşkü'nden Harem-i Hümayûn'a hareket.." Buna göre, III. Mustafa'nın kılıç kuşanma merasimi ve tahta çıkışı, burada tersanedeki gemilerin sancaklarla donatılması ile Tersane, Tophane ve Kurşunlu Mahzen'den topların atılması vasıtasıyla kutland1 ${ }^{71}$.

III. Mustafa'nın ölümü ile onun yerine tahta çıkan (21 Ocak 1774) Sultan I. Abdülhamid (17741789)'te geleneğe uygun bir şekilde tahta çıkışının altınc1 günü Eyüp Sultan Türbesi'ne giderek kılıç kuşand $1^{72}$. Abdülhamid'in kılıç kuşanma töreninin başka bir kaynakta tahta çıkışının yedinci günü olan 27 Ocak Perşembe günü gerçekleştirildiği belirtilmektedir ${ }^{73}$. Yine döneme ait belgelerde de padişahın kılıç kuşanma merasiminin cülusunun yedinci günü olduğu belirtilmektedir ${ }^{74}$. Buna göre Sultan Abdülhamid alışılagelen uygulamanın dışına çıkarak Hz. Ömer'in kılıcının yerine Hz. Peygamber'in kılıcını kuşandı. Padişaha bu mübarek kılıç, eski nakibü'l-eşraf ve yeni Şeyhülislâm Şerif-zâde Mehmed tarafindan kuşandırıld ${ }^{75}$. Benzer ifadeler dönemin kroniklerinde de geçmekte olup, Sultan Abdülhamid geleneğe uygun bir şekilde cülusunun altıncı günü Fatih Sultan Mehmed türbesini ziyaret ettikten sonra Eyüb Sultan türbesine giderek kılıç kuşanmıştır ${ }^{76}$. Nitekim Sultan Abdülhamid'in kılıç kuşanma merasimi ile ilgili dönemin kroniklerinden Sadullah Enverî Efendi'nin tarihinde geçen ifadeler şu şekildedir ${ }^{77}$ :

"Şehr-yâr-ı ma'delet-ger-dâr hazretleri cülûs-ı hümâyûnlarlyla meymenet-bahş-ı emsâr ü aktâr olduklarının altıncı hamîs günü rikâb-ı hümâyûndan vürûd edenlerinden tahkik olunduğu vech ile kavânîn-i kadîme-i ecdâd-ı 'izâm ve merâsim-i dîrîne-i mer 'iyye âbâ-kirâmların ihyâ buyurmak içün

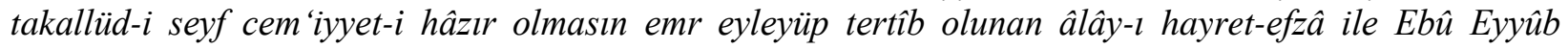
Ensârî merkad-ı münevverelerine 'azîmet ve bu yüzden müşâhede-i cemâl-aftâb misâlleri ümîdiyle yemîn ü yesâr-ı tarîkde dîz-ıl intizâr olan halâyı-encüm şumâra selâm-bahş̧ ü 'atâ-pâş̧ olarak isticlâb-ı kulub-ı erâmil ü z'afâya dikkat ve hilâl-ı râhda Ebû'l-feth ve'l-megazî Sultân Mehmed Hân Gazi hazretlerinin dahi merkad-ı rıdvân-ma 'hedlerin ziyâret eyledikden sonra ihtiyâr olunan sâ' ât-ı nehârîden yedinci sâ'at duhîl edinceye dek türbe-i Hâlid'den du 'â vü istifâzaya klyâm ve bi'l-yümn ve'l-ikbâli't-tâmm nakib-i sâbık Şeyhü'l-islâm Şerif-zâde Mehmed Mollâ Efendi yediyle takallüd-i hüsâm-ı behrâma intikal eyleyüp manend-i aftâb sarây-ı hümâyûnlarına iyâb buyurdular".

$\mathrm{Bu}$ arada padişahın kılıç kuşanma alayı için Kalfa Kapısı'ndan “daire-i şahane”ye kadar çeşitli kumaşlar döşendi ${ }^{78}$.Yine Sultan Abdülhamid'in geleneklere uygun bir şekilde kılıç kuşanma merasimi

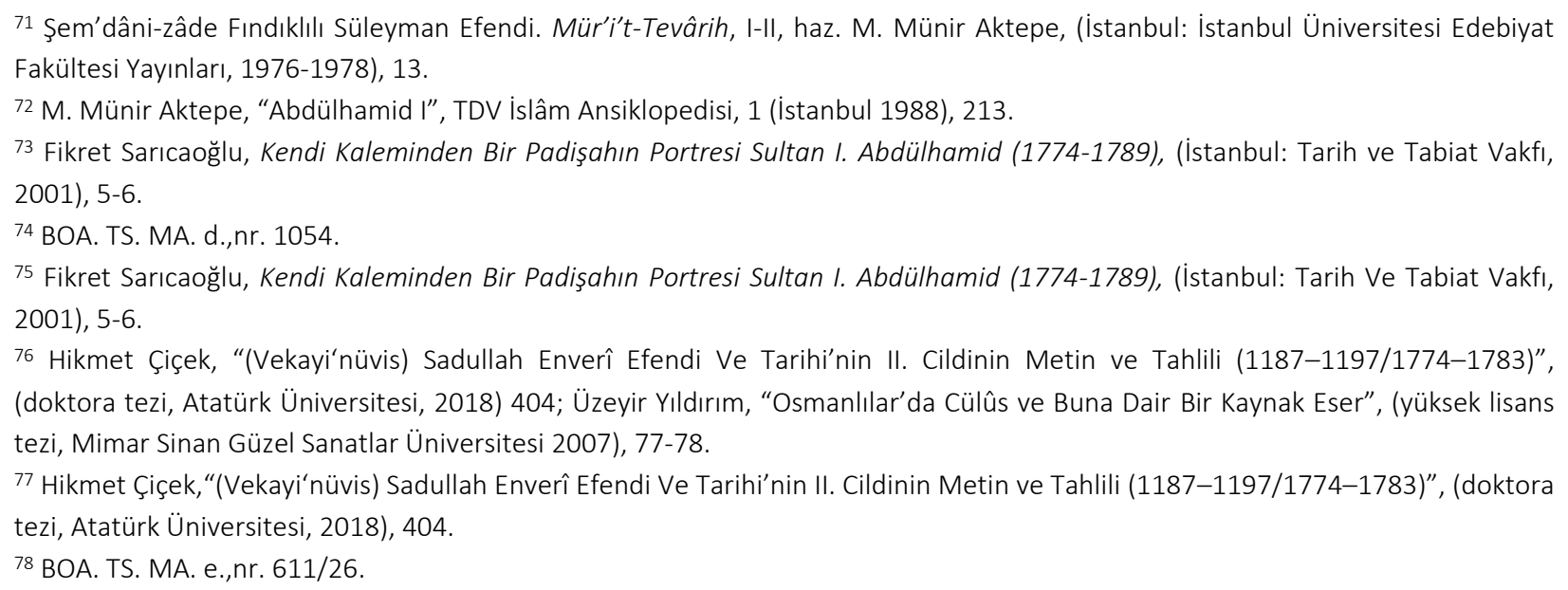


öncesinde, sırasında ve sonrasında bir takım görevlilere atiyyeler verdiği bilinmektedir. Bu sırada verilen atiyye ve ihsanlar şu şekildedir: ${ }^{79}$

Tablo-2: Sultan I. Abdülhamid'in Kılıç Kuşanma Merasiminde Atiyye Verilen Görevliler ve Atiyye Miktarları ${ }^{80}$

\begin{tabular}{|l|l|}
\hline \multicolumn{1}{|c|}{ Kime Verildiği } & \multicolumn{1}{|c|}{ Verilen Miktar } \\
\hline Türbeye teşriflerinde ceyb-i hümâyûna teslim olunan cedid sikke & 300 adet zer-i mahbub-1 tam \\
\hline $\begin{array}{l}\text { Bab-1 hümâyûndan Eyüb Ensari’ye varınca 19 kıta yeniçeri ve 7 kita } \\
\text { cebeci kullarına Çukadar Ağa yediyle verilen miktar }\end{array}$ & 540 adet zer-i mahbub-1 tam \\
\hline $\begin{array}{l}\text { Baş Çukadar Ağa yediyle esna-yı rahda ocak aşçlarına ve kara } \\
\text { kullukçuyan ve sakalarına verilen miktar }\end{array}$ & $\begin{array}{l}\text { 691 adet zer-i mahbub-1 tam } \\
81 \text { adet zer-i mahbub-1 nısf }\end{array}$ \\
\hline Yeniçeri Sakarına & 8 adet zer-i mahbub-1 tam \\
\hline Sultan Mehmed türbedarlarına & 50 adet zer-i mahbub-1 tam \\
\hline Sultan Mehmed Cami-i şerif hademeleri kullarına & 500 kuruş \\
\hline $\begin{array}{l}\text { Sultan Mehmed türbesinde hatim eden İmam Efendi vekiline 20, aslına } \\
80\end{array}$ & 100 kuruş \\
\hline $\begin{array}{l}\text { Bab-1 hümâyûndan Eyüb Ensari’ye varınca Hazinedar Ağa ve Hazinee } \\
\text { Kethüdası tarafindan verilen para }\end{array}$ & 11500 kuruş (23 kese) \\
\hline Katar ile giden başyazıcı ve ikinci yazıcı ve hazine eskileri kullarına & 300 kuruş \\
\hline Maiyetlerinde giden teberdarân-1 hassa kullarına & 300 kuruş \\
\hline Eyüb Ensari Türbedarları kullarına & 500 kuruş \\
\hline Eyüb Ensari'de feth-i şerif kırrat eden kullara & 50 adet 50 adet zer-i mahbub-1 tam \\
\hline
\end{tabular}

XVIII. yüzyılın son padişahı olan III. Selim (1789-1807) ise kılıç kuşanma geleneğine göre padişahların kılıç kuşanmadan Cuma namazına gitmeme kaidesi gereğince Salı günü tahta çıkmasına rağmen kılıç alay1 7 gün sonra Pazartesi günü icra edildi ${ }^{81}$. Buna göre 7 Nisan 1789 tarihinde tahta çıkan Sultan Selim için 17 Nisan 1789'da kılıç alayı gerçekleştirildi ${ }^{82}$. Bununla ilgili olarak kılıç kuşanma merasiminin nasıl olacağı hakkında şeyhülislamın reisülküttaba gönderdiği tezkire, sadrazamın telhisiyle padişaha arz edildi ${ }^{83}$. Nitekim bununla ilgili olarak Osmanlı tarihindeki cülus merasimleriyle ilgili bir sadaret defterindeki ifadeler Sultan Selim'in kılıç kuşanma merasiminin 17 Receb 1203 (13 Nisan 1789) tarihinde icra edildiğini göstermektedir ${ }^{84}$.

Merasimde mutat uygulamalara dikkat edilirken ${ }^{85}$ III. Selim'in kılıç kuşanma alayı için belgelere yansıyan kayıtlara göre 30.150 kuruş harcand $1^{86}$. Bu miktarın 1.077 kuruş 50 akçesi padişah ve maiyetinin Eyüp Sultan Türbesi'ne gidişi sırasında yollara dökülen kum için harcand1 ${ }^{87}$. Yine döneme ait başka bir belgede padişahın kılıç kuşanma merasimi için nakit olarak harcanan ve esnaftan satın alınan eşyalar için toplamda 61.102,5 kuruş ödendiği tespit edilebilmektedir ${ }^{88}$. Ayrıca III. Selim kılıç kuşanma merasimi

79 BOA. TS. MA. d., nr.1054.

80 BOA. TS. MA. d., nr.1054.

81 Ruhan Dinç, "18. Yüzyılda Osmanlı Merasimlerinin Mali Bir Unsuru: Atıyyeler", (yüksek lisans tezi, Fatih Sultan Mehmet Vakıf Üniversitesi 2016) , 36.

82 Kemal Beydilli, "Selim III", TDV İslâm Ansiklopedisi, 36 (İstanbul 2009), 425.

83 BOA. TS. MA. e. , nr. 756/114.

84 Üzeyir Yıldırım, "Osmanlılar'da Cülûs ve Buna Dair Bir Kaynak Eser", (yüksek lisans tezi, Mimar Sinan Güzel Sanatlar Üniversitesi 2007),114, 115-117

85 Üzeyir Yıldırım, “Osmanlılar'da Cülûs ve Buna Dair Bir Kaynak Eser”, (yüksek lisans tezi, Mimar Sinan Güzel Sanatlar Üniversitesi 2007) 112-114

86 BOA. TS. MA. d. , nr. 5138.001.

87 BOA. C. DH. nr. 334/16673.

88 BOA. TS. MA. d. , nr. 5138. 002. 
sonrasında eskiden beri devam eden kaidelere uymak suretiyle bir takım görevlilere toplamda 640 altın atiyye verdi. "Taklid-i seyf" için atiyye verilen bu görevliler ve miktarlar şu şekildedir:"

Tablo-3: Sultan III. Selim'in Kılıç Kuşanma MerasimindeAtiyye Verilen Görevliler ve Atiyye Miktarları

\begin{tabular}{|l|c|}
\hline \multicolumn{1}{|c|}{ Verilen Kişi/Görevli } & Miktar (Adet) \\
\hline Berâ-yı kayıkçıyân ez-bostâniyân-1 hâssa & 200 \\
\hline Berâ-yı teşrifâtî efendi & 40 \\
\hline Berâ-yı pişkeşci-i hâssa & 20 \\
\hline Berâ-yı matharacı-1 hâssa & 15 \\
\hline Berâ-yı iskemleci-i hâssa & 15 \\
\hline Berâ-yı nevbetciyân-1 bevvâbin-i dergâh-1 âlî & 30 \\
\hline Berâ-yı ferrâş-1 seccâde-i şehriyârî der-türbe-i şerife & 5 \\
\hline Berâ-yı bevvâbin-i Bâb-1 Hümâyûn & 15 \\
\hline Berâ-yı bevvâbin-i bâb-1 miyân & 15 \\
\hline Berâ-yı ser-bölükhân-1 bevvâbin-i dergâh-1 âli & 15 \\
\hline Berâ-yı nevbetciyân-1 çavuşân-1 dergâh-1 âli & 30 \\
\hline Berâ-yı çavuşân der-Bâb-1 Hümâyûn & 15 \\
\hline Berâ-yı çavuşân der-Bâb-1 Sadr-1 âli & 15 \\
\hline Berâ-yı solakan-1 hâssa & 50 \\
\hline Berâ-yı peykân-1 hâssa & 60 \\
\hline Berâ-yı halîfe-i teşrifât efendi & 20 \\
\hline Kise-i teşrifât & 20 \\
\hline $\begin{array}{l}\text { Fî 18 CA sene 1223 Sultan Mahmud Efendimizin seyf alayında zamm olunan Çavuşân-1 } \\
\text { alaya }\end{array}$ & 15 \\
\hline Yamağ-1 kise-i teşrifât-1 hümâyûna & 15 \\
\hline TOPLAM & $\mathbf{6 4 0}$ \\
\hline
\end{tabular}

$\mathrm{Bu}$ şekilde kılıç kuşanma merasimi icra edilen III. Selim hükümdarlığın bir gereği olarak kabul edilen ve kılıç alayı yapılmadan yeni padişahın Cuma selamlığına çıkmama prensibini bozdu. Buna göre "kılıç kuşanma töreni padişahların geleneği, Cuma farzı ise Allah'ın emridir" diyen padişah, kılıç kuşanmadan önce Cuma namazını Ayasofya Camii’nde kıldı ${ }^{90}$.

${ }^{89}$ Üzeyir Yıldırım, “Osmanlılar’da Cülûs ve Buna Dair Bir Kaynak Eser”, (yüksek lisans tezi, Mimar Sinan Güzel Sanatlar Üniversitesi

2007), 117.

${ }^{90}$ Abdülkadir Özcan "Kılıç Alayı", TDV İslâm Ansiklopedisi, 8 (Ankara 2002), 410. 


\section{Sonuç}

Osmanlı Devleti'nde kılıç, eski Türk devlet geleneğinin bir devamı olarak merasimlerin önemli bir simgesi olmuştur. Nitekim Osmanlı tarihinde kuruluş yıllarından itibaren saray gelenekleri arasında yerini alan kılıç kuşanma merasimleri, her dönemde halkın ve devletin ileri gelenlerinin ilgisini çeken önemli bir seremoni haline gelmiştir. Resmi belgelerde "taklid-i seyf, takallüd-i şemşîr" olarak geçen bu merasimler, kılıç alayı ve kılıç kuşanma olmak üzere iki aşamadan oluşur. Tarihi temelleri İslâm'ın ilk dönemlerine kadar dayanan bu merasimler, Osmanlılar zamanında kendine özgü motifler kazanmıştır. Genellikle padişahların cüluslarının ikinci ile yedinci günü arasında gerçekleştirilen bu merasimler, padişahların iktidarlarını meşrulaştıran manevi ve resmî bir mahiyet arz ederken, aynı zamanda halkın padişaha ulaşabilmesinin de bir vesilesidir. Kılıç kuşanma merasimleri padişahın sabahın erken saatlerinde saraydan çıkışıyla başlar ve gösterişli bir alay eşliğinde Eyüp Sultan Türbesi'nde dualarla icra edilirdi. XVII. yüzyılda saltanatın temel sembollerinden biri haline gelen kılıç kuşanma merasimleri, çalışmanın konusunu oluşturan XVIII. yüzyılda da birtakım küçük değişimlerle varlığını devam ettirdi. Nitekim yüzyılın ilk padişahı olan III. Ahmed geleneğin dışına çıkarak kılıç kuşanma merasimini tahta çıkışından bir ay sonra gerçekleştirdi. Bu durum padişahın bir isyan hadisesi sonrasında tahta geçmesiyle ilgili zorunlu bir gecikmedir. Bunun dışında III. Ahmed'in kılıç kuşanma merasiminde mutat uygulamalara uyuldu. Benzer bir gecikme halefi I. Mahmud'un merasiminde de yaşandı. 1730 isyanı sonrasında tahta geçen padişahın kılıç kuşanma töreni tahta geçişinden yirmi bir gün sonra icra edildi. Yine önceki dönemlerden farklı olarak I. Mahmud, III. Ahmed gibi, isyancılara gözdağı vermek amaciyla Hz. Muhammed'in kılıcını kuşandı. Son olarak padişah geleneğin dışına çıkmak suretiyle merasim için gidiş ve dönüşte kara yolunu kullandı. Dönemin üçüncü padişahı olan Sultan III. Osman'ın kılıç kuşanma merasiminde ise merasim sonrası saraya değil, Yalı-köşkü’ne gidilmesi dışında bir farklılık yaşanmadı. Padişahın 1757'de ölümüyle yerine tahta geçen Sultan III. Mustafa'da geleneğe uygun bir şekilde tahta çıkışının beşinci günü kılıç kuşandı. Yine padişahın kılıç alayı ve merasiminde diğer tüm mutat uygulamalara dikkat edilirken, merasim için çeşitli görevlilere önemli ihsanlarda bulunuldu. 1774'de tahta geçen I. Abdülhamit ve son olarak 1789'da tahta çıkan III. Selim'in kılıç kuşanma merasimleri de benzer şekilde geleneğin icrası şeklinde gerçekleştirilirken, her iki merasimde de görevlilere önemli ihsanlarda bulunuldu. III. Selim bir istisna olarak, geleneğin dışına çıkmak suretiyle Cuma namazını kıldıktan sonra, kılıç kuşandı. Görüldüğü üzere XVIII. yüzyılda kılıç kuşanma merasimleri Osmanlı Devleti'nde daha önceki yüzyıllarda teamül haline gelen geleneklere uymak suretiyle icra edildi. Çalışmada tespit edilen bazı küçük farklılıkların ise dönemin kendi özel şartları içerisinde ve sürecin anlam ve önemine etki etmeyecek boyutlarda olduğu sonucuna varıldı. Bu noktada özellikle XVIII. yüzyıl saray teşrifatı içerisinde yer alan benzer merasimlerle ilgili yapılacak mukayeseli çalışmalar, ilgili yüzyılda yaşanan değişimleri ortaya çıkartacak önemli argümanlar sunacaktır. 


\section{KAYNAKLAR}

\section{Arşiv Kaynakları}

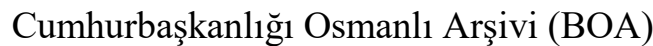

HH. nr. 524/25602.

C. SM. nr. 1/29; nr. 132/6636.

C. DH. nr. 334/16673.

TS. MA. e.nr. 611/26; 756/114.

TS. MA. d., nr.2352.0889; 1054; 5138.001; 5138.002.

\section{Diğer Kaynaklar}

Aktepe, M. Münir. “Abdülhamid I”, TDV İslâm Ansiklopedisi, 1, (İstanbul 1988),.213-216.

Aktepe, M. Münir. “Ahmed III”, TDV İslâm Ansiklopedisi, 2 (1989), 34-38.

Anonim Osmanlı Tarihi (1099-1116/1688-1704), (Yay. Haz. Abdülkadir Özcan), Ankara: TTK. Yayınları, 2000.

Alderson, A. D. Osmanlı Hanedanının Yapısı, çev. Şefaettin Severcan, İstanbul: İz Yayıncılık, 1998.

Alikılıç, Dündar. Osmanlı'da Devlet Protokolü ve Törenler Imparatorluk Seremonisi, İstanbul: Tarih Düşünce Kitapları, 2004.

Aydın, Hilmi. “Topkapı Sarayı'nda Padişah Kılıçları”, El Sanatları Dergisi, 4 (2007): 28-37.

Başkurt, Ahmet Çağrı “351 Numaralı Sadaret Teşrifat Defteri Işı̆̆ında Osmanlı Payitahtında İcra Edilen Törenler (H. 1105-1221/M. 1693-1806)", Yüksek lisans tezi, Mimar Sinan Güzel Sanatlar Üniversitesi, 2017.

Baykal, Ebru. “Osmanlılarda Törenler”, Yüksek lisans tezi, Trakya Üniversitesi, 2008.

Beydilli, Kemal. "III. Mustafa (1757-1774). Kaynarca Öncesi bir Padişah Portresi”, Kitab-ı Hedaya, Studien zum Osmanischen Reichundseinen Nachbargebieten, Hg. Sevgi Ağcagül-HenningSivert, Bonn: Bonn Univesity Press, 189-249.

Beydilli, Kemal. "Mustafa III”, TDV İslâm Ansiklopedisi, 31 (İstanbul 2006), 280-283.

Beydilli, Kemal. “Selim III”, TDV İslâm Ansiklopedisi, 36 (İstanbul 2009),.425-426.

Bikkul, Ahat Ural. “Topkapı Sarayı Müzesindeki Türk Kılıçları Üzerinde Bir İnceleme”, Türk Etnografya Dergisi, IV, Ankara: TTK Basımevi (1962), 20-30.

Bozkurt, Nebi. "Kılıç”, TDV İslâm Ansiklopedisi, 25 (Ankara 2002),405-408.

Coşkun, Feray. "Osmanlı İstanbul'unda Müstesnâ bir Ziyaretgâh: Eyüp Sultân Türbesi”, III. Osmanlı İsstanbul'u Sempozyum Bildirileri 1, İstanbul: 25-26 May1s 2015.

Çiçek, Hikmet. “(Vekayi'nüvis) Sadullah Enverî Efendi Ve Tarihi’nin II. Cildinin Metin ve Tahlili (1187-1197/1774-1783)”, Doktora tezi, Atatürk Üniversitesi, 2018. 
Defterdar Sar1 Mehmed Paşa, Zübde-i Vekayiat Tahlil ve Metin (1066-1116/1656-1704), (haz. Abdülkadir Özcan), Ankara: TTK. Yayınları, 1995.

Dinç, Ruhan. “18. Yüzyılda Osmanlı Merasimlerinin Mali Bir Unsuru: Atıyyeler”, Yüksek lisans tezi, Fatih Sultan Mehmet Vakıf Üniversitesi, 2016.

Görür, Cem. "Sultan III. Mustafa: Ailesi, Günlük Hayat1, Dini ve İlmi İlgileri”, Doktora tezi, Bilecik Şeyh Edebali Üniversitesi, 2020.

Günyol, Vedat. “Kılıç Alayı”, İslâm Ansiklopedisi, 6 (İstanbul 1977), 678-679.

Kafadar, Cemal. “Eyüp’te K1lıç Kuşanma Törenleri”, Eyüp: Dün/Bugün Sempozyum 11-12 Aralık 1993, haz. Tülay Artan, İstanbul 1994.

Karateke, Hakan T. Padişahım Çok Yaşa Osmanlı Devleti'nin Son Yüzyllında Merasimler, İstanbul: Türkiye İş Bankası Kültür Yayınları, 2017.

Koparal, Özlem Günday. "Osmanlı Minyatürlerinde Merasim Tasvirleri”, Yüksek lisans tezi, Dokuz Eylül Üniversitesi, 2019.

Kurtaran, Uğur. Sultan Birinci Mahmud (1730-1754), Ankara: Altınordu Yayınları, 2018.

Irmak, Yunus. "III. Mustafa Ruznamesi (H. 1171-1177/M. 1757-1763)”, Yüksek lisans tezi, Marmara Üniversitesi, 1991.

İnalcık, Halil. “Osmanlı Padişahı”, A. Ü. S. B. F. D., C. XIII/IV, (1958), 68-79.

Mehmed Hâkim Efendi, Hâkim Efendi Tarihi, (Osmanlı Tarihi 1166-1180/1752-1766) (Inceleme-Metin), C. I, haz. Tahir Güngör, ed. Ziya Yılmazer, (İstanbul: Türkiye Yazama Eserler Kurumu Başkanlığı, 2019).

Özcan, Abdülkadir. “İstanbul'da Cülus ve K1lıç Kuşanma Törenleri”, Antik Çağdan XXI. Yüzyıla Büyük İstanbul Tarihi, Siyaset ve Yönetim II, C.3, İstanbul (2015), 384-395.

Özcan, Abdülkadir. “Kılıç Alayı”, TDV İslâm Ansiklopedisi, 8 (Ankara 2002), 408-410.

Özcan, Abdülkadir. “Cülus”, TDV İslâm Ansiklopedisi, 8 (İstanbul 1993),108-114.

Sakaoğlu, Necdet. “Sultan I. Mahmud”, Bu Mülkün Sultanlarl, İstanbul (2004),328-347.

Sağlam, Nevzat. “Ahmed Vâsıf Efendi ve Mehâsinü'l-Asâr ve Hakâ'iku'l-Ahbâr'1 1166-1188/1752-1774 (İnceleme ve metin)", Doktora Tezi, Marmara Üniversitesi, 2014.

Sarıcaoğlu, Fikret. “Osman III”, TDV İslâm Ansiklopedisi, 33 (İstanbul 2007), 456-459.

Sarıcaoğlu, Fikret. Kendi Kaleminden Bir Padişahın Portresi Sultan I. Abdülhamid (1774-1789), İstanbul: Tarih ve Tabiat Vakfi, 2001.

Sevinç, Bayram. "Yiğit ve Silahlı Adam Diyalektiğinde Kılıç Simgesi”, Turkish Studies, 8/6, Ankara (2013): 619-639.

Şem'dâni-zâde Fındıkl11ı Süleyman Efendi. Mür'i't-Tevârih, C. I-II, Haz. M. Münir Aktepe, İstanbul: İstanbul Üniversitesi Edebiyat Fakültesi Yayınları, 1976-1978. 
Tanrıbuyurdu, Gülçin. "Klâsik Türk Şiirinde "Kılıç Duası", Divan Edebiyatı Araştırmaları Dergisi 9, (2012): 139-166.

Tezcan, Hülya. Osmanlı Sarayının Çocukları, Şehzadeler ve Hanım Sultanların Yaşamları, Giysileri, İstanbul: Aygaz Yayınları, 2006

Topal, Mehmet. Silahdar Fındıklı Mehmed Ağa, "Nusretname- Tahlil ve Metin (1106-1133/ 1695-1721)", Doktora Tezi, Marmara Üniversitesi, 2001.

Tozduman Terzi, Arzu. "Sultan Abdülaziz’in Kılıç Kuşanma Merasimi”, Osmanlı ’nın İzinde Profesör Dr. Mehmet İpşirli Armağanı, C. II, haz. F. M. Emecen, İshak Keskin, Ali Ahmetbeyoğlu, İstanbul: Timaş Yayınları, 2013.

Uzunçarşı11, İsmail Hakkı. Osmanlı Devleti'nin Saray Teşkilâtı, Ankara: TTK Yayınları, 2014.

Vak’anüvis Subhî Mehmed Efendi. Subhî Tarihi, haz. Mesut Aydıner, İstanbul: Kitabevi Yayınları, 2007.

Yıldırım, Üzeyir. “Osmanlılar'da Cülûs ve Buna Dair Bir Kaynak Eser”, Yüksek lisans tezi, Mimar Sinan Güzel Sanatlar Üniversitesi, 2007. 